\title{
Rational Distribution Channel Mix for Lifestyle Brands in India - An Empirical Study
}

\author{
H. R. Ganesha ${ }^{1}$, \& P. S. Aithal ${ }^{2}$ \\ ${ }^{1}$ Chief Executive Officer - Consulting Division, Gramss Retail Trading Private Limited, \\ Bengaluru - 560078, India and Post-Doctoral Research Fellow, College of Management \& \\ Commerce, Srinivas University, Mangalore - 575001, India. \\ OrcidID: 0000-0002-5878-8844; E-mail: hrganesha@yahoo.co.in \\ ${ }^{2}$ Vice Chancellor, Srinivas University, Mangalore - 575001, India. \\ OrcidID: 0000-0002-4691-8736; E-mail: psaithal@gmail.com
}

Area of the Paper: Business Management.

Type of the Paper: Empirical Research.

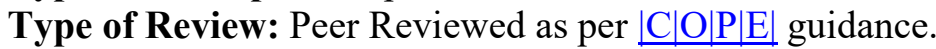

Indexed In: OpenAIRE.

DOI: http://doi.org/10.5281/zenodo.3925852.

Google Scholar Citation: IJCSBE.

\section{How to Cite this Paper:}

Ganesha, H. R., \& Aithal, P. S. (2020). Rational Distribution Channel Mix for Lifestyle Brands in India - An Empirical Study. International Journal of Case Studies in Business, IT, and Education (IJCSBE), 4(1), 136-154. DOI: http://doi.org/10.5281/zenodo.3925852.

International Journal of Case Studies in Business, IT and Education (IJCSBE)

A Refereed International Journal of Srinivas University, India.

(C) With Authors.

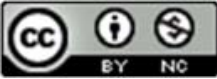

This work is licensed under a Creative Commons Attribution-Non-Commercial 4.0 International License subject to proper citation to the publication source of the work.

Disclaimer: The scholarly papers as reviewed and published by the Srinivas Publications (S.P.), India are the views and opinions of their respective authors and are not the views or opinions of the S.P. The S.P. disclaims of any harm or loss caused due to the published content to any party. 


\title{
Rational Distribution Channel Mix for Lifestyle Brands in India - An Empirical Study
}

\author{
H. R. Ganesha ${ }^{1}$, \& P. S. Aithal ${ }^{2}$ \\ ${ }^{1}$ Chief Executive Officer - Consulting Division, Gramss Retail Trading Private Limited, \\ Bengaluru - 560078, India and Post-Doctoral Research Fellow, College of Management \& \\ Commerce, Srinivas University, Mangalore - 575001, India. \\ OrcidID: 0000-0002-5878-8844; E-mail: hrganesha@yahoo.co.in \\ ${ }^{2}$ Vice Chancellor, Srinivas University, Mangalore - 575001, India. \\ OrcidID: 0000-0002-4691-8736; E-mail: psaithal@gmail.com
}

\begin{abstract}
Indian lifestyle brands need to understand the importance of their retailing distribution channels in relation to their overall brand image, products / categories they offer, target consumer group and their implications on the overall brand profitability and consumer perceptions over the brand image rather applying standard thumb rules, assumptions and misconceptions followed by other generalist brands or even short-term lucrative deals offered by distribution channel partners. It is evident that only few Indian brands are able to create true lifestyle brand image in their employees, investors, competitors and consumers mind and trueness level of majority of Indian lifestyle brands is still a question. Majority of developing and developed Indian lifestyle brands assume that the success of a lifestyle brand is measured basis the revenue or profit they generate through having presence across wider distribution channels and are impatient / unaware of implicit long-term strategical benefits of creating a true lifestyle brand image in consumers mind using a rational distribution channel mix strategy. It is true that India is one of the countries with consumers belonging to the widest range of Religions, Regions, Languages, Sub-Cultures and Economic backgrounds which makes it very difficult for any lifestyle brand to have their presence across the country through various distribution channels as each one of them have their own pros and cons for the brand. This makes it furthermore important for lifestyle brands in India to be more careful and efficient in ensuring the adaptation of rational distribution channel mix. It is observed that the majority of Indian lifestyle brands believe they have adopted the right distribution channel mix and it is yielding the best possible revenue and profit. This belief / assumption always distracts them from analysing the pros and cons of each distribution channel with respect to the overall brand image and they rather spend most of their time in finding sales channels which are new or latent in nature to be added to the existing distribution channel mix. In this research, we have analysed twelve months actual sales data across various distribution channels available in India of few select lifestyle brands and drawn insights to recommend a rational distribution channel mix for lifestyle brands in India.
\end{abstract}

Keywords: Indian Retail, National Brand, Lifestyle Brand, Indian Lifestyle Brand, Distribution, Distribution Channel Mix, Retail Distribution Channels in India, Brand Image, Store Choice, Store Locations, Store Count Ratio.

\section{INTRODUCTION :}

1.1 Store location choice determines most of the lifestyle brand's operating costs, be it fixed or variable in nature viz., distribution channel partner's sales commission, retailer's minimum guarantee, rent, common area maintenance (CAM) costs, number of sales personnel, house-keeping charges, maintenance costs, security related costs, etc. Sales commission and rental component of this cost 
structure contribute to the largest part of the fixed cost structure of a lifestyle brand and the same varies by store location and / or distribution channel partner in addition to steady increase year-on-year on pre-agreed terms. Distribution channel partner's sales commission and / or rent is one of the most important costs in retailing which holds a significant share of overall retailing cost structure and most importantly due to its fixed cost nature they become even more important aspects of retailing which has a direct impact on overall brand revenue and profitability. One could argue that a lifestyle brand must open stores and / or shop-in-shops (SIS) in locations which attract a larger number of consumers who are willing to spend more, but unfortunately, it is not that simple, store location choice for lifestyle brands is truly a complex task and majority of the time more attractive the location and distribution channel partner more expensive it is for the brand. Every lifestyle brand needs to have their presence in different locations to have a strategic and competitive advantage as far as brand's image in consumers, competitors and employees mind are concerned and hence it is inevitable for lifestyle brands to open few stores in premium locations and also tie-up with costly distribution channel partners. Consumer's store and retailer choice angle to store location is the one which puts many lifestyle brands in a quandary while considering the store location. By its nature, this decision is capital intensive and requires the retailer to commit long-term lock-ins with the property owners and sign up for minimum guarantee clauses with reputed distribution channel partners. Every lifestyle brand thus, expects the store location to attract many relevant consumers, generate higher revenue and profits failing which could lead lifestyle brands to spend additional money to attract and acquire consumers to the store. The store location becomes even more important for lifestyle brands offering multiple categories to multiple consumer groups, catering to multiple life-stage needs of a consumer and comprising of many products/categories which are designed to serve specific needs of consumers. Store location is also one of the most important determinants for lifestyle brands as far as retail expansion is concerned. The popular location choices available for lifestyle brands in India are i) Multi-Branded Outlets (MBO) operated by local, regional, and national level retailers / distributors, ii) Online Marketplaces, and iii) Offline / Online Exclusive Brand Outlets (EBO). It is inevitable for lifestyle brands to have their presence in as many different locations and distribution channel partner's stores as possible to have a competitive advantage over competitors and unorganized local favourites. But, all the stores, all the locations, all the cities and all the distribution channel partners in a particular country behave differently in terms of revenue and profits they generate for the brand.

1.2 Lifestyle Brand: Each individual want to have a unique identity which could be based on his / her a) background such as nationality, ethnicity, culture, subculture, social class, affiliation, environment, etc; b) experiences, and c) choices. Lifestyle brands in fact attempt to evoke emotional connections between consumers and their need to have a unique identity and most importantly lifestyle brands are increasingly becoming one of the key components of consumer's self-expression [1]. To ensure the scope of this study is focussed, we define lifestyle brands as the ones, which attempt to offer a complete solution for a specific or wider lifestyle needs of consumers through their products such as Apparel, Footwear and Accessories with an ultimate goal of their products being key contributors of an implicit or explicit statement of consumers personality and identity. Lifestyle retail market size in India is expected to reach 130 billion USD by the year 2023 which is a 77 percent growth when compared to year 2013 [2]. Based on India's 2011 census, United Nation's (UN) Department of Statistics and Programme Implementation estimates Indian population to reach close to 1.38 billion by the year 2020 [3]. It is estimated that more than 300 Global lifestyle brands have plans to open their stores in India this year [4]. In addition to this humongous population, exponential growth in a number of working women, double income families, middle-class consumer segment, increasing disposable income, rapid adoption of fashion, urbanization, overall size of Indian retail industry, more and more unorganized retailers becoming organized, emergence of modern retailing formats and most importantly enormous increase in internet penetration / usage, simply caution existing and upcoming lifestyle brands to revisit their brand building strategies.

1.3 Lifestyle Brands in India: Owing to the sheer market size and potential, India is able to attract many Global lifestyle brands. Few Global brands have attempted to offer their product assortment as being a SIS at select large MBO stores, few have offered their product assortment through having EBOs, few have shown their presence only in online stores and few have licensed their brands to third parties or entered into a Joint Venture to offer their products in Indian retail market. To name a few 
Levi's, Zara, United Colors of Benetton, Marks \& Spenser, H\&M, Mother Care, Carter's, Puma, Nike, Adidas, Reebok, Armani Exchange, Diesel, Gas, Gap, The Children's Place, Quiksilver, Superdry, Kappa, Bossini, Calvin Klein, Hanes, Tommy Hilfiger, Ed Hardy, Izod, Nautica, Arrow, U.S. Polo Assn, Jack \& Jones, Vero Moda, Tumi, Lee, Hero, Maverick, Wrangler, Fila and Jockey. Unless these Global lifestyle brands explore sourcing their products predominantly from India, competitive pricing remains one of the key challenges as far as their sustainable success in the Indian market is concerned. India also a home fora vast number of lifestyle brands originated from India. One can possibly list more than 5000 lifestyle brands in India [5], of which few of them are have strong presence all over India, few have a strong presence only in certain regions of India and few are available only online. It is evident that, in spite of such humongous number of lifestyle brands available in India one could possibly list only a few which can be tagged as well-known / familiar / reputed Indian lifestyle brands such as, Biba, Manyavar, Soch, Gini \& Jony, Blackberrys, Louis Phillipe, Peter England, Provogue, Monte Carlo, Mufti, W for Women, Oxemberg, Indian Terrain, Global Desi, Parx, S Kumar's, Vimal, Mini Klub, Aurelia, Sparx, Campus, Go Colors, Enamour, HiDesign, Lino Perros, Idee, Spykar, Killer Jeans, Flying Machine, Da Milano, Park Avenue, Ethnix, ColorPlus, Lux Cozy, Wild Craft, 612 League, WLS, John Players, Fastrack, 109 F, Proline, Image, Jealous 21, Liberty, Paragon and few more. Only a few names from the list of more than 5000 brands possibly indicating that despite of humongous population and the retail market size in India, majority of Indian lifestyle brands have failed to establish themselves as true lifestyle brands and we would attribute the majority of this failure to their existing distribution channel strategy in addition to their existing Marketing Mix.

1.4 Distribution Channels in Indian: Figure 1 depicts a typical distribution channel mix of lifestyle brands in India. Indian retail market, despite of being significantly skewed towards unorganized retailing has also witnessed many organized retailers and distribution channels relevant for a lifestyle brand such as; MBO Local Retailers: These are Multi-Branded brick-and-mortar stores managed by retailers having their presence only in a particular city of India and allow lifestyle brands to showcase and sell their products through a shop-in-shop method (For example, Channabasappa \& Sons Davanagere, Karnataka). MBO Regional Retailers: These are Multi-Branded brick-and-mortar stores managed by retailers having their strong presence in specific regions of India and allow lifestyle brands to showcase and sell their products through a shop-in-shop method (For example, Kapsons Punjab). MBO National Retailers: These are Multi-Branded brick-and-mortar stores managed by retailers having their presence all over India and allow lifestyle brands to showcase and sell their products through a shop-in-shop method (For example, Shoppers Stop). EBO Offline: These are brick-andmortar stores selling products belonging to the brand exclusively. EBO Online: Online store selling products belonging to the brand exclusively $M B O$ Speciality Online Retailers: These are MultiBranded online stores managed by retailers and focussed on specific categories of products and allow lifestyle brands to list and sell their products (For example, Myntra).MBO Generalist Online Retailers: These are Multi-Branded online stores managed by retailers and mostly sell all the categories of products and allow lifestyle brands to list and sell their products (For example, Flipkart) [6]. Dominantly majority of lifestyle brands in India have shown presence in just one or a few of these channels and very few have shown their presence in multiple distribution channels across the country. Few established lifestyle brands have also taken advantage of their brand image and brand equity to attract franchisee partners to operate EBO stores which are known to be one of the best ways to expand brand presence through EBO stores without huge capital investments from the brand. Post emergence of online marketplaces majority of new Indian lifestyle brands have their presence predominantly in online marketplaces. It is also important to note that majority of brands appoint distribution agencies to manage regional and local MBO stores. 


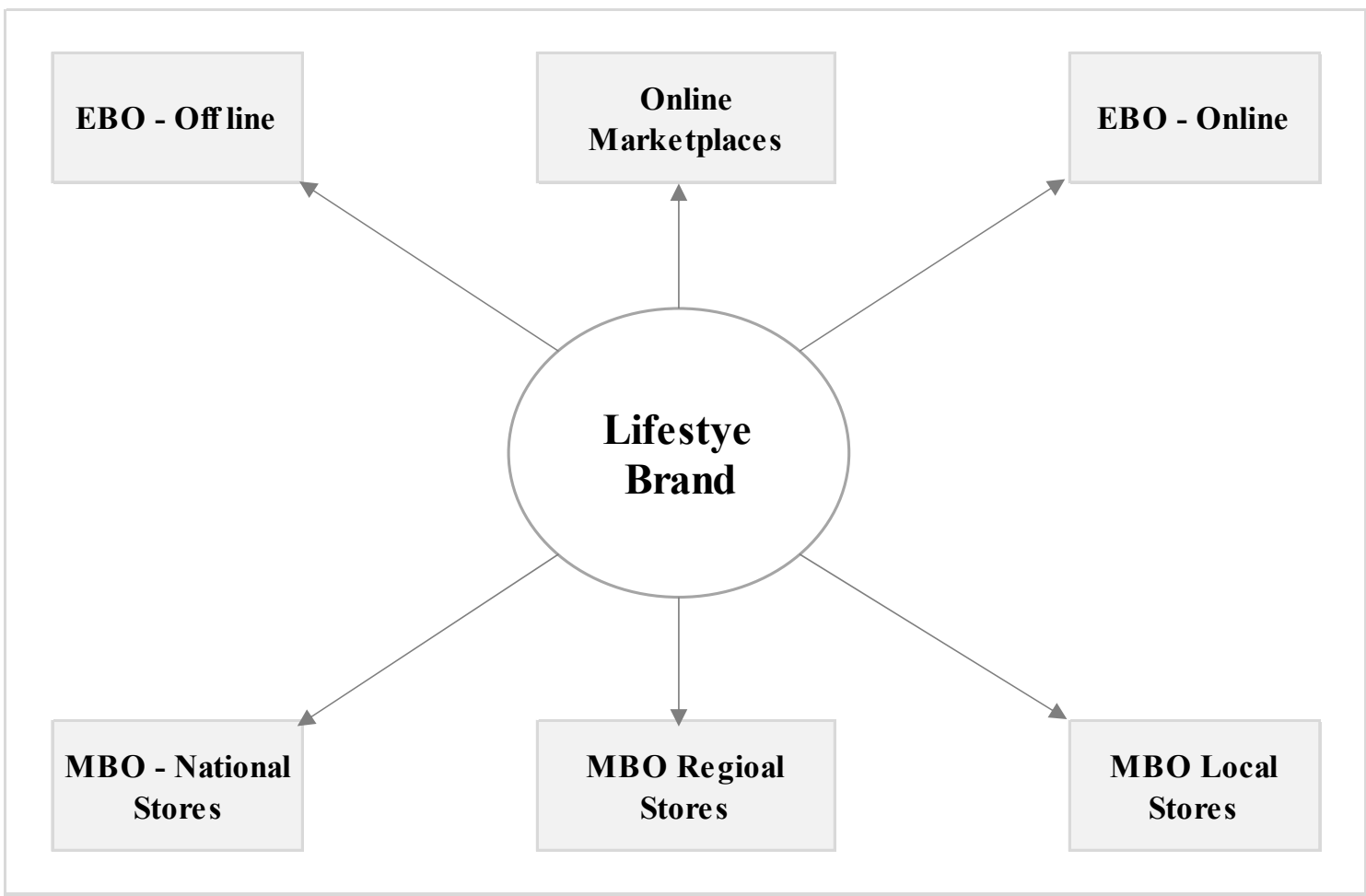

Fig.1: Typical distribution channel mix of lifestyle brands in India

\section{LITERATURE REVIEW :}

2.1 Retailing location had been one of the key elements of retailing mix studied in the past. Lindquist was the first to list the key components of store image construct in the year 1974. Based on past studies Lindquist listed eight components of store image construct viz., i) merchandise, ii) clientele, iii) physical facilities, iv) convenience, v) promotion, vi) store atmosphere, vii) institutional factors, and viii) post-transactional satisfaction [7]. Later researchers have confirmed that the basic attributes of store image construct as listed by Lindquist in 1974 remain unchanged [8] and were able to add few more attributes to store image constructs such as ix) customer service, $\mathrm{x}$ ) personal selling and $\mathrm{xi}$ ) sales incentive programs [9]. Few studies argue that these factors together influence the overall store image in consumers mind only when the consumers have experienced these factors through actual shopping [10]. There have been many studies confirming a positive correlation between store layout and consumer loyalty [11 - 13]. Consumers perception of store image varies with store layout and consumers shopping at different store formats having different store layouts create their own perception of store image in their mind [14]. Extending these studies recommend bricks-and-mortar retailers to align their store layout design keeping their target consumers in mind rather adopting standard layout designs [15]. Retailers need to consider various location specific factors while planning for expansion such as a) attractiveness of the market, b) number of stores to be opened per market, c) store locations and d) ideal store size for each of these stores. In this study, they clearly indicate that, every store needs to have size optimal for the location and market it is present rather a standard size being adopted across all the stores of a particular retailing format. In all these studies nowhere, researchers recommend retailers to adopt different price level of merchandise for different locations of stores [16]. A retailer having a unique store image and using this unique store image as one of the key promotional and marketing/advertising propositions can possibly yield competitive advantage and it is important to note that copying a store image which is complex in its nature is a difficult task for competitors [17]. One of the most important determinants of retailer success is store image [18]. Retailers need to clearly understand various environmental factors relating to store an image influencing their target consumers. It is very important to design strategies relating to store image in a specific location in relation to retailers target consumers in that particular environment [19]. Majority of retailers design strategies relating to specific locations based on the consumer behaviour pattern and knowledge available in the 
general market in the specific location which is also based on the general consumer population [20]. These strategies lead retailers to align most of the store image attributes to the general consumer population and hence they might possibly fail to maintain their principal brand/store image standard across various locations or geographies. Retailer's store success and consumer loyalty is majorly influenced by store image along with store positioning and product-price differentiation in relation to market. Retailers could possibly use such store image attributes to promote and advertise their positioning in the consumers mind [21-22]. Store location is not just about the physical space which has been occupied by a store, it is actually a catchment area of a store which witnesses heavy commercial and economic activities [23]. Store size and location are most important components of retailing as far as enhancing consumer experience is concerned. Few reputed retail brands like Zara have increased their store sizes exponentially along with changing the type of locations in the past, few retail brands such as Debenhams and Mother Care have downsized their existing store sizes to incorporate improved operating efficiencies, few retail brands such as Tesco entered city centre locations with smaller sized stores, few continually kept rationalizing their store sizes and few still believe that larger the store size higher the consumer walk-ins [24]. One of the biggest challenges faced by brick-and-mortar retailers is the higher cost involved in expanding store sizes even though it helps them in enhancing overall consumer shopping experience. Retailers are finding it extremely difficult to find relevant spaces in right locations owing to higher rentals and lesser spaces available in key retail locations [25], proposes retailers to consider mall kiosks as one possible retailing format which can be cost effective as far as expensive rentals are concerned. It is true that store location plays an influential role in consumer store choice decisions, at the same time store location being a long-term capital lockin decision plays an important role for retailer's overall strategy planning. Any location which has inherent properties of attracting consumers is a best location for any retailer and having a store in such locations brings both strategic and competitive advantages to retailer, whereas, it will take longer time and huge store losses for any retailer to come out of a bad store location. Good store location could also be analysed by; a) the amount of relevant consumer traffic flow be it, pedestrian traffic or vehicular traffic; b) parking facilities; c) store composition; d) specific site; e) terms of occupancy, f) accessibility, g) travelling time, h) location convenience, and i) other complimentary stores present in the catchment [26]. Through our previous empirical and experimental research studies, we have concluded that:(i) if retailer considers building premium store image in consumers, competitors, and investors mind as the key indicator of judging best location for a store, mall stores are the ideal ones, and if the retailer is interested in overall retail performance with consistent growth and sustainable profits then a rational mix of each of these locations is the ideal solution [27]; (ii) there is no significant variance in contribution of different price bands to overall bills / invoices and revenue being generated by stores across Tier 1, Tier 2 and Tier 3 cities for a retailer who runs all these stores under a single store brand name and results have shown that stores in Tier 2 and Tier 3 cities generate lesser revenue compared to Tier1 city stores and this must not be mistaken as consumers in cities other than Tier1 cities face affordability issue [28]; and(iii) the fourth and important elements of Marketing Mix 'place' need be aligned based on the product / category grouping in relation to target consumer group and catchment area [6].

2.2 Consumer preference or choice of brand and success of a brand depends upon the brand's personality. It is important for the marketer to constantly work on strategies to convert the existing brand image into equity [29]. Few researchers have investigated the correlation among the competition of brands, formation of consumers' attitude and intention to choose a particular brand or alternatives being offered to the consumers at a given point of time and the place of the offering. Findings of these studies confirm that consumers' evaluations, understandings, and knowledge about a particular brand of their choice are not just the key influencer of creating intentions of buying a product belonging to a brand, it is also consumers' perspectives and perceptions toward another alternative or brand available in the offering [30]. There are few brands which have gained strong brand equity owing to consumers having special, favourable association with such brands in their memories and these brands were able to create higher perceived quality, awareness about the brand name and ultimately leading huge loyal consumers over a period of time [31-33]. Consumers tend to correlate their personality with the brand personality they are willing to associate with, wherein they attribute this to their demographic characteristics, physical characteristics, personal traits and, cognitive abilities consequently leading 
them to buy a brand's product to implicitly or explicitly express / showcase their personal image or identity [34-35]. Abundant literature is available on Brand personality, image, equity, experience, association, advertisement, endorsements, and loyalty as a result of contributions from many researchers across domains.

2.3Distribution channel mix is one of the most important aspects of lifestyle brand's marketing strategy. Once the brand defines or recognizes its target consumer group, the brand needs to constantly attempt to ensure that their products are made available in as many relevant places as possible, thereby enabling consumers to find these products at the right time in the right place when they need them [36]. There are many distribution channel partners available in the market, but what is very important for the brands is to clearly understand the key objectives of these partners in relation to brand's business objectives [37]. Lifestyle brands need to also understand that distribution channel partners are independent of brand's control and channel partners interest is in attracting as many consumers as possible to their stores thereby making it inevitable for the lifestyle brands to integrate their brand marketing strategies with their channel partners on a constant and consistent basis [38]. It is not just about communicating brand's promotional activities with the channel partners, it is all about how the brand manages these channel partners efficiently across all the "4P's" of brand's Marketing Mix to convey to brand's target consumer group [39 - 40]. Multichannel distribution and multichannel promotion are two different things, integration among various distribution channels using information technology is a must for any lifestyle brand which would develop long-term relationships with their consumer groups irrespective of their retailer choice as consumers are only bothered about the brand they intend to associate with and therefore these consumers must not be void of any information about the brand and its products / promotions just because they are shopping in different retailing channels [41]. Studies have also argued that consumers who are using multiple distribution channels to purchase products tend to spend more as compared to consumers using a single channel of retailing for their purchases [42].

Need for this research aroused when we found that majority of empirical, theoretical, and descriptive literature available on overall distribution channel mix/ strategy focusses on consumer's perspective and not on the brand's perspective. We were not able to find relevant literature which guides lifestyle brands with respect to store locations choice, and store locations mix and an overall distribution channel mix with which we could answer our research questions such as; a) should we believe that the existing distribution channel mix of lifestyle brands in India is an appropriate strategy?; b) should we believe that the existing distribution channel mix is delivering optimal revenue and profit for the brands?; c) should we believe that the existing distribution channel strategy is aligned with brand's target consumers?; d) is it a misconception among lifestyle brands in India that consumers are attracted to stores / retail formats located in premium locations and in turn they tend to spend more? and most importantly; e) has the brand aligned its distribution channel strategy with its key goal of building sustainable brand equity and true lifestyle brand image among its employees, investors, competitors, and consumers mind? Thus, we decided to select few national level Indian lifestyle brands, understand their existing distribution channel mix spread across different types of distribution channels, empirically evaluate their actual sales and consumer data in relation to channel partners and brand's key goal, thereby drawing insights to recommend lifestyle brands in India the right distribution channel strategy to gain long-term strategic and competitive advantage in addition to establishing a true lifestyle brand image across their existing and potential employees, investors, competitors and consumers mind.

\section{OBJECTIVES :}

Key objectives of this research were to, i) understand lifestyle brands market in India; ii) understand evolution and performance of Indian lifestyle brands; iii) understand unit economics of various distribution channels available in India; iv) understand existing distribution channel mix of few select Indian lifestyle brands; v) analyse recommendations from previous research studies; vi) design and propose a rational distribution channel mix and vii) recommend systematic approach for executing the new distribution channel strategy.

\section{METHODOLOGY :}


4.1 Secondary Research: Intense and in-depth analysis of data available in the public domain was carried to collect data relating to various aspects of lifestyle brands in India through company websites, company annual financial reports, Government data base, trade, and business journals. Research works relating to Indian lifestyle brands were surveyed extensively to collect insights, recommendations, and frameworks.

4.2 Quantitative Primary Research: In the first stage, few lifestyle brands in India were selected who can represent, a) different product categories such as fashion, functional, life-stage specific, product specific, gender specific, and need specific products; b) offering single-product category and multipleproduct categories; c) serving different consumer target groups at low, mid-low, mid, mid-high, high, and premium price positioning; d)selling their products through local retailers either directly or using distributors, regional retailers either directly or using distributors, national retailers, EBOs operated directly by the brand, EBOs operated by the franchisee partners, online EBO store operated either directly or using third parties and, online marketplaces; e) products manufactured from own factory and contract manufacturers (both inside and outside India); f) across developing brands, developed brands, and, established brands. In the second stage, twelve months actual data was collected from these select lifestyle brands to quantitatively map their existing distribution channel mix and draw inferences.

4.3 Qualitative Primary Research: Series of open-ended direct interviews were conducted with employees selected through convenience sampling representing different departments/functions from Brands, Distributors and Retailers viz., Human Resource Development, Training, Strategy, Category, Communication, Customer Relationship, Warehousing, Finance, Information Technology, Sales, Distribution, Stores Operation along with Store Sales Personnel to understand their perspective and attitude towards existing distribution channel mix and its implications on the overall brand performance and image.

\section{KEY FINDINGS AND INSIGHTS :}

5.1 Qualitative: Prior to the empirical study, we were able to derive qualitative insights through mystery shopping and conduct open-ended direct interviews with employees representing all the departments and functions of lifestyle brands chosen for the study. Key insights from the qualitative survey indicate that, the brand strongly had numerous beliefs and assumptions as detailed below for each distribution channel type.

SIS Stores: a) It is very difficult to get entry in to National retailer's stores as they require the brand to have minimum level of product assortment width and depth, b) National retailers require the brand to sign up for a minimum guarantee clause, c) National retailers expect and pressurize brands to have efficient supply chain systems, d) National retailers pay the brand on $10^{\text {th }}$ to $15^{\text {th }}$ of every month based on actual sales of previous month and this affect brand's cash flow, e) National retailers return majority of unsold stocks after a specific season is complete, f) Regional retailers do not pay on-time, g) Regional retailers are yet be evolved as far as systematic retailing is concerned, h) Regional retailers have less number of stores, i) Distribution stores are controlled by the distributors and brand need to pay additional commission to distributors, $\mathrm{j}$ ) payment from distributors is irregular, $\mathrm{k}$ ) distributors overpower the brand in the selection of product assortment, and 1) in spite of an outright purchase and products being predominantly selected by them they fail to sell all the products within a specific period of time thereby pressurizing brand to accept the goods return after a season is over.

EBO Brick-and-Mortar Stores: a)It is very difficult to attract new consumers to EBO high street stores, b) lot of marketing money has to be spent to acquire new consumers to EBO high street stores, c) EBO high street stores need to have additional security cost, d) EBO high street stores maintenance becomes additional work for the store sales personnel, e)rent is higher in EBO high street stores, $\mathrm{f}$ ) EBO mall stores help us create premium brand image in consumers mind, g) EBO mall stores attract lot of new consumers, $\mathrm{h}$ ) marketing money spent for consumer acquisition is much lesser in EBO mall stores, h) EBO malls get huge consumer walk-ins/traffic, i) common area maintenance is taken care by the EBO mall management, j) EBO mall stores have greater security systems, k) EBO institutional stores do not generate significant revenue, 1) EBO institutional stores run only to acquire new consumers for other stores in the city, $\mathrm{m}$ ) consumers treat EBO institutional stores for one-time purchases and most importantly, $\mathrm{n}$ ) consumers in the EBO mall stores are premium consumers and 
they tend to buy more compared to EBO high street and EBO institutional stores and most importantly, and o) EBO distribution channel is most capital intensive channel for the brand.

Online Stores: a) It is impossible to sell goods online without offering substantial discounts due to which brands inflate original price (MRP) to the extent of discount level which is perceived by consumers as great deal or sell only old products with an intention of liquidation, b) it is very easy to list brand's product assortment in online stores irrespective of product assortment's width and depth available and irrespective of brand being new or old in the market, c) brand needs to spend lot on consumer acquisition and logistics if associated with online stores, d) online channel gives quick entry to the brand to reach consumers directly, e) online stores generate the highest revenue per store per month, f) online stores cater to wider group of consumers and does not require the brand to hold on to specific price positioning, region or consumer group.

5.2 Empirical: Interestingly, when we evaluated actual data related product assortment, sales, consumers, distribution channel partner commercials, inventory level, inventory turns, product sell through and velocity, we have found many insights which are contrary to what was believed by the lifestyle brands as detailed below for each distribution channel type.

SIS Stores: Majority of lifestyle brand in the study were unaware of the concept of 'unit economics. Thus, we attempted to understand the unit economics of SIS stores across National, Regional, Local and Distributor stores which could possibly enable us to understand the MBO SIS distribution channel empirically rather than just looking at the qualitative pros and cons of the channel. Table 1 shows the end to end flow of parameters for a lifestyle brand at MBO SIS stores. Each of these parameters have been tagged with a) controlled by channel partner, b) controlled by the lifestyle brand, c) controlled by the Government agencies, d) controlled by consumers and e) derived numbers. This tagging helps one to understand the key areas which can be controlled by the lifestyle brand and its existing / potential consumers, work on designing processes / systems to make these controllable efficient rather worrying about parameters which are controlled by the channel partners. Whatever said and done, it is very important and inevitable for lifestyle brands to have their presence in this distribution channel as this channel does not require the brand to commit any larger capital investments and most importantly these channels already have their existing consumer base. The results indicate that, though the National retailer stores generate higher revenue for the brand they fail to generate profit for the brand unless brand performance is more than their expected minimum guarantee levels. Distributor stores though low in generating revenue they possibly generate profit for the brand in addition to having capability of enhancing brand's presence across the country in larger scale.

EBO Brick-and-Mortar Stores: In our previous empirical study we have noted that premium EBO locations and city Tier does not guarantee higher store level profits in addition to the misconception of the brand is also proven in the statistical significance t-test which captures correlations between all the independent variables and overall store profit among high street, mall, and institutional stores. When we look at the correlations using per store per month values (magnitude) which is what the brand follows for strategic decision making, most of the correlations are positive and insignificant with 0.000 2 -tailed sig. value. Whereas, if we take a look at the correlations using per square foot values (which is the most important determinant as far as store operating costs are concerned) then statistical results indicate; a) a strongly positive but insignificant correlation between bills and overall store profit in high street stores; b) a strongly positive significant correlation between bills and overall store profit in mall stores; c) a weakly positive but significant correlation between discount per cent and overall store profit in institutional stores; d) a weakly positive and insignificant correlation between discount per cent and overall store profit in high street stores; e) a weakly positive and insignificant correlation between discount per cent and overall store profit in mall stores; f) a moderately negative but insignificant correlation between discount per cent and overall store profit in institutional stores; g) a moderately negative but insignificant correlation between discount per cent and overall store profit in institutional stores; h) a moderately negative but insignificant correlation between discount per cent and overall store profit in institutional stores [27 - 28]. Same as SIS distribution channel, we have attempted to understand the unit economics of EBO stores across different types of locations such as high street, mall and institutional which could possibly enable us to understand the EBO distribution channel empirically rather than just looking at the pros and cons of the channel. Table 2 shows the end to end flow of parameters for a lifestyle brand at EBO stores in different type of locations. Each of 
these parameters has been tagged with a) controlled by channel partner, b) controlled by the lifestyle brand, c) controlled by the Government agencies, d) controlled by consumers, and e) derived numbers. This tagging helps one to understand the key areas which can be controlled by the lifestyle brand and its existing / potential consumers, work on designing processes / systems to make these controllable efficient rather worrying about parameters which are controlled by the realty partner. The results indicate that, though the EBO mall stores generate higher revenue for the brand they fail to generate profit for the brand. EBO institutional stores though low in generating revenue they possibly generate higher absolute profit values for the brand in addition to having capability of being located very close to relevant target consumer groups. EBO high street stores have shown balanced results across revenue and profit.

Online Stores: Table 3 shows the end to end flow of parameters for a lifestyle brand at online stores in different type of platforms such as EBO online stores and online marketplaces. Each of the parameters has been tagged with a) controlled by channel partner, b) controlled by the lifestyle brand, c) controlled by the Government agencies, d) controlled by consumers, and e) derived numbers. This tagging helps one to understand the key areas which can be controlled by the lifestyle brand and its existing / potential consumers, work on designing processes / systems to make these controllable efficient rather worrying about parameters which are controlled by the channel partner. Results indicate that, though the online distribution channels generate higher revenue for the brand on the per store per month basis, they fail to generate profit for the brand and in fact they generate significant losses to the brand. In comparison to other distribution channels online stores have shown higher annual inventory turns, nevertheless it is also noted that this could be moderated by significantly higher levels of discounts being offered to consumers as compared to other distribution sales channels. Most significant issue which was completely ignored by the lifestyle brands was the issue of stock returns from the consumers. We have noted that about 26.69 percent of products sold to consumers were returned back to brand owing to various issues and this is one of the major concerns as far as return logistics cost is concerned which directly affects the overall brand profitability at store level in addition to creating unsatisfied consumers, wrong perception about the brand image and most importantly negative wordof-mouth.

Table 4 indicates comparison among various distribution channels with respect to magnitude of performance indicators whereas, Table 5 shows the percentage deviation across key factors among various distribution channels from lifestyle brand's national level mean. Some of the beliefs which do match with results are mostly skewed to absolute numbers (magnitude) and that too related to revenue generation per store per month and not the efficacy levels such as overall brand profitability at store level per store per month as well as per store per square foot productivity. In table 6 we have captured the percentage deviation across key factors among brick-and-mortar and online distribution channels from lifestyle brand's national level mean which clearly indicates that brick-and-mortar stores in addition to generating store level profits, also enable the lifestyle brand to expand their store presence across the country using various distribution channels available. 
Table 1: Store level unit economics of SIS stores for lifestyle brands in India.

\begin{tabular}{|c|c|c|c|c|}
\hline $\begin{array}{l}\text { Particulars } \\
\text { (An example of Men's Apparel Category) }\end{array}$ & Nature of the Particulars & $\begin{array}{r}\text { SIS at National } \\
\text { Retailer Stores }\end{array}$ & $\begin{array}{l}\text { SIS at Regional } \\
\text { Retailer Stores }\end{array}$ & $\begin{array}{r}\text { SIS at Distributor } \\
\text { Stores }\end{array}$ \\
\hline SIS Trading Area (SFT) & Decided by the Channel Partner & 200 & 150 & 50 \\
\hline Common Area Loading (\%) & Decided by the Channel Partner & $34 \%$ & $34 \%$ & $34 \%$ \\
\hline SIS Carpet Area (SFT) & Derived Parameter & 267 & 200 & 67 \\
\hline Display Density per SFT (Pieces) & Decided by the Channel Partner & 5.0 & 5.0 & 5.0 \\
\hline Minimum Display Quantity (Pieces) & Derived Parameter & 1000 & 750 & 250 \\
\hline Sizes & Decided by the Lifestyle Brand & S:M:L:XL & S:M:L:XL & S:M:L:XL \\
\hline Size Ratio & Decided by the Lifestyle Brand & $1: 3: 3: 1$ & $1: 3: 3: 1$ & $1: 3: 3: 1$ \\
\hline Quantity per Size Set (Pieces) & Derived Parameter & 9 & 9 & 9 \\
\hline Minimum Size Sets per Store & Decided by the Lifestyle Brand & 2 & 2 & 2 \\
\hline Minimum Display Options & Derived Parameter & 56 & 42 & 14 \\
\hline Average MRP (INR) & Decided by the Lifestyle Brand & 964 & 964 & 964 \\
\hline MRP Multiplier Factor & Decided by the Lifestyle Brand & 3.5 & 3.5 & 3.5 \\
\hline Average Product Base Cost (INR) & Derived Parameter & 275 & 275 & 275 \\
\hline Minimum Display Inventory Value at MRP (INR Lacs) & Derived Parameter & 9.64 & 7.23 & 2.41 \\
\hline Minimum Display Inventory Value at Cost (INR Lacs) & Derived Parameter & 2.75 & 2.07 & 0.69 \\
\hline Annual Inventory Turns & Decided by the Consumers & 4.13 & 2.68 & 1.10 \\
\hline Sales Quantity (Pieces per Month) & Derived Parameter & 344 & 168 & 23 \\
\hline Return Sales Quantity (Pieces per Month) & Decided by the Channel Partner & 10 & 2 & 0 \\
\hline Net Sales Quantity (Pieces per Month) & Derived Parameter & 334 & 166 & 23 \\
\hline Sales MRP Value (INR Lacs per Month) & Derived Parameter & 3.22 & 1.60 & 0.22 \\
\hline Annual Discount Provision (\%) & Decided by the Lifestyle Brand & $15 \%$ & $15 \%$ & $5 \%$ \\
\hline Discount Value (INR Lacs per Month) & Derived Parameter & 0.48 & 0.24 & 0.01 \\
\hline Gross Sales Value (INR Lacs per Month) & Derived Parameter & 2.74 & 1.36 & 0.21 \\
\hline Average Selling Price (INR per Piece) & Derived Parameter & 819 & 819 & 915 \\
\hline SPF (INR) & Derived Parameter & 34 & 23 & 10 \\
\hline Secondary Tax (\%) & Decided by the Government & $5 \%$ & $5 \%$ & $5 \%$ \\
\hline Secondary Tax Value (INR Lacs per Month) & Derived Parameter & 0.13 & 0.06 & 0.01 \\
\hline Reve nue (INR Lacs per Month) & Derived Parameter & 2.61 & 1.29 & 0.20 \\
\hline Cost of Goods Sold (INR Lacs per Month) & Derived Parameter & 0.92 & 0.46 & 0.06 \\
\hline Gross Earning Value (INR Lacs per Month) & Derived Parameter & 1.82 & 0.90 & 0.15 \\
\hline Gross Earning (\%) & Derived Parameter & $66 \%$ & $66 \%$ & $70 \%$ \\
\hline Distributor Commission (\%) & Decided by the Distributor & $\mathbf{0 \%}$ & $\mathbf{0 \%}$ & $10 \%$ \\
\hline Distributor Commission Value (INR Lacs per Month) & Derived Parameter & $\mathbf{0}$ & $\mathbf{0}$ & 0.02 \\
\hline Retailer Sales Commission (\%) & Decided by the Channel Partner & $38 \%$ & $35 \%$ & $30 \%$ \\
\hline Retailer Sales Commission Value (INR Lacs per Month) & Derived Parameter & 1.04 & 0.56 & 0.07 \\
\hline MPF (INR) & Derived Parameter & 13 & 8 & 3 \\
\hline Brand Staff Cost (INR Lacs per Month) & Decided by the Lifestyle Brand & 0.20 & 0.20 & $\mathbf{0}$ \\
\hline Brand Promotional Cost Provision (INR Lacs per Month) & Decided by the Lifestyle Brand & 0.19 & 0.07 & 0.01 \\
\hline Warehousing Expenses (INR Lacs per Month) & Decided by the Lifestyle Brand & 0.11 & $\mathbf{0}$ & $\mathbf{0}$ \\
\hline Logistics Expenses (INR Lacs per Month) & Decided by the Lifestyle Brand & 0.007 & 0.003 & 0.000 \\
\hline Shrinkage Provision (INR Lacs per Month) & Decided by the Lifestyle Brand & 0.021 & $\mathbf{0}$ & $\mathbf{0}$ \\
\hline Minimum Guarantee (MPF INR) & Decided by the Channel Partner & 15.00 & $\mathbf{0}$ & $\mathbf{0}$ \\
\hline Minimum Guarantee Value (INR Lacs per Month) & Derived Parameter & 1.20 & 0.00 & 0.00 \\
\hline Minimum Guarantee Cost (INR Lacs per Month) & Derived Parameter & 1.20 & 0.00 & 0.00 \\
\hline Total Retailing Cost (INR Lacs per Month) & Derived Parameter & 2.77 & 0.83 & 0.10 \\
\hline Net Earning Value (INR Lacs per Month) & Derived Parameter & -0.95 & 0.07 & 0.05 \\
\hline Net Earning (\%) & Derived Parameter & $-35 \%$ & $5 \%$ & $23 \%$ \\
\hline Net Earnings per Piece Sold (INR) & Derived Parameter & -277 & 43 & 204 \\
\hline Purchase Mode & Decided by the Channel Partner & SOR & SOR & OR \\
\hline Basis for Payment to Lifestyle Brand & Decided by the Channel Partner & $\begin{array}{r}\text { Actual Sale to } \\
\text { Consumer }\end{array}$ & $\begin{array}{r}\text { Actual Sale to } \\
\text { Consumer }\end{array}$ & $\begin{array}{r}\text { Actual Billing to } \\
\text { Distributor }\end{array}$ \\
\hline Payment Terms & Decided by the Channel Partner & $\begin{array}{r}30 \text { Days from the } \\
\text { date of actual Sale } \\
\text { to Consumer }\end{array}$ & $\begin{array}{r}45 \text { Days from the } \\
\text { date of actual Sale } \\
\text { to Consumer }\end{array}$ & $\begin{array}{r}30 \text { to } 180 \text { Days } \\
\text { from the date of } \\
\text { Billing to Distributor }\end{array}$ \\
\hline
\end{tabular}

MBO: Multi-Branded Outlet; SFT: Square Foot; SPF: Sales per Square Foot per Day; MPF: Margin Value per Square Foot pe Day; SOR: Sale-or-Return; OR: Outright 
Table 2: Store level unit economics of brick-and-mortar EBO stores for lifestyle brands in India.

\begin{tabular}{|c|c|c|c|c|}
\hline $\begin{array}{l}\text { Particulars } \\
\text { (An example of Men's Apparel Category) }\end{array}$ & Nature of the Particulars & $\begin{array}{r}\text { EBO } \\
\text { High Street } \\
\text { Store }\end{array}$ & $\begin{array}{r}\text { EBO } \\
\text { Mall } \\
\text { Store }\end{array}$ & $\begin{array}{r}\text { EBO } \\
\text { Ins titutional } \\
\text { Store }\end{array}$ \\
\hline Trading Area (SFT) & Decided by the Lifestyle Brand & 2000 & 2000 & 800 \\
\hline Common Area Loading (\%) & Decided by the Lifestyle Brand & $34 \%$ & $34 \%$ & $34 \%$ \\
\hline Carpet Area (SFT) & Derived Parameter & 2672 & 2672 & 1069 \\
\hline Display Density per SFT (Pieces) & Decided by the Lifestyle Brand & 5.0 & 5.0 & 5.0 \\
\hline Minimum Display Quantity (Pieces) & Derived Parameter & 10000 & 10000 & 4000 \\
\hline Sizes & Decided by the Lifestyle Brand & S:M:L:XL & S:M:L:XL & $\mathrm{S}: \mathrm{M}: \mathrm{L}: \mathrm{XL}$ \\
\hline Size Ratio & Decided by the Lifestyle Brand & $1: 3: 3: 1$ & $1: 3: 3: 1$ & $1: 3: 3: 1$ \\
\hline Quantity per Size Set (Pieces) & Derived Parameter & 9 & 9 & 9 \\
\hline Minimum Size Sets per Store & Decided by the Lifestyle Brand & 2 & 2 & 1 \\
\hline Minimum Display Options & Derived Parameter & 556 & 556 & 444 \\
\hline Average MRP (INR) & Decided by the Lifestyle Brand & 964 & 964 & 964 \\
\hline MRP Multiplier Factor & Decided by the Lifestyle Brand & 3.5 & 3.5 & 3.5 \\
\hline Average Product Base Cost (INR) & Derived Parameter & 275 & 275 & 275 \\
\hline Minimum Display Inventory Value at MRP (INR Lacs) & Derived Parameter & 96.40 & 96.40 & 38.56 \\
\hline Minimum Display Inventory Value at Cost (INR Lacs) & Derived Parameter & 27.54 & 27.54 & 11.02 \\
\hline Annual Inventory Turns & Decided by the Consumers & 2.85 & 2.92 & 2.62 \\
\hline Sales Quantity (Pieces per Month) & Derived Parameter & 2375 & 2433 & 873 \\
\hline Return Sales Quantity (Pieces per Month) & Decided by the Lifestyle Brand & 24 & 24 & 9 \\
\hline Net Sales Quantity (Pieces per Month) & Derived Parameter & 2351 & 2409 & 865 \\
\hline Sales MRP Value (INR Lacs per Month) & Derived Parameter & 22.67 & 23.22 & 8.33 \\
\hline Annual Discount Provision (\%) & Decided by the Lifestyle Brand & $18 \%$ & $18 \%$ & $14 \%$ \\
\hline Discount Value (INR Lacs per Month) & Derived Parameter & 4.00 & 4.10 & 1.19 \\
\hline Gross Sales Value (INR Lacs per Month) & Derived Parameter & 18.67 & 19.12 & 7.15 \\
\hline Average Selling Price (INR per Piece) & Derived Parameter & 794 & 794 & 827 \\
\hline SPF (INR) & Derived Parameter & 23 & 24 & 22 \\
\hline Secondary Tax (\%) & Decided by the Government & $5 \%$ & $5 \%$ & $5 \%$ \\
\hline Secondary Tax Value (INR Lacs per Month) & Derived Parameter & 0.89 & 0.91 & 0.34 \\
\hline Revenue (INR Lacs per Month) & Derived Parameter & 17.78 & 18.21 & 6.81 \\
\hline Cost of Goods Sold (INR Lacs per Month) & Derived Parameter & 6.48 & 6.64 & 2.38 \\
\hline Gross Earning Value (INR Lacs per Month) & Derived Parameter & 12.19 & 12.49 & 4.76 \\
\hline Gross Earning (\%) & Derived Parameter & $65 \%$ & $65 \%$ & $67 \%$ \\
\hline MPF (INR) & Derived Parameter & 15 & 16 & 15 \\
\hline Institution Commission (\%) & Decided by the Institution & $\mathbf{0 \%}$ & $\mathbf{0 \%}$ & $15 \%$ \\
\hline Institution Commission Value (INR Lacs per Month) & Derived Parameter & $\mathbf{0}$ & $\mathbf{0}$ & 1.02 \\
\hline Rent per SFT (INR per Month) & Decided by the Realty Partner & 150 & 200 & $\mathbf{0}$ \\
\hline Store Rent Value (INR Lacs per Month) & Derived Parameter & 4.01 & 5.34 & $\mathbf{0}$ \\
\hline CAM per SFT (INR per Month) & Decided by the Realty Partner & $\mathbf{0}$ & 50 & $\mathbf{0}$ \\
\hline Store CAM Value (INR Lacs per Month) & Derived Parameter & $\mathbf{0}$ & 1.34 & $\mathbf{0}$ \\
\hline SFT Covered by One Sales Personnel & Decided by the Lifestyle Brand & 300 & 300 & 300 \\
\hline Sales Personnel Head Count & Derived Parameter & 9 & 9 & 4 \\
\hline Store Managers Head Count & Decided by the Lifestyle Brand & 2 & 2 & 1 \\
\hline Store House Keeping Personnel Head Count & Derived Parameter & 1 & 1 & 0 \\
\hline Store Security Personnel Head Count & Derived Parameter & 1 & 0 & 0 \\
\hline Total Employee Cost (INR Lacs per Month) & Derived Parameter & 2.02 & 1.92 & 0.78 \\
\hline Store Overheads per SFT (INR per Month) & Decided by the Lifestyle Brand & 50 & 40 & 15 \\
\hline Store Overheads Cost (INR Lacs per Month) & Derived Parameter & 1.34 & 1.07 & 0.16 \\
\hline Bank and Finance Charges (INR Lacs per Month) & Derived Parameter & 0.28 & 0.29 & 0.11 \\
\hline Brand Promotional Cost Provision (INR Lacs per Month) & Decided by the Lifestyle Brand & 1.31 & 1.34 & 0.50 \\
\hline Warehousing Expenses (INR Lacs per Month) & Decided by the Lifestyle Brand & 0.71 & 0.73 & 0.27 \\
\hline Logistics Expenses (INR Lacs per Month) & Decided by the Lifestyle Brand & 0.71 & 0.73 & 0.27 \\
\hline Shrinkage Provision (INR Lacs per Month) & Decided by the Lifestyle Brand & 0.233 & 0.239 & 0.089 \\
\hline Total Retailing Cost (INR Lacs per Month) & Derived Parameter & 10.60 & 12.99 & 3.21 \\
\hline EBITDA Value (INR Lacs per Month) & Derived Parameter & 1.59 & -0.50 & 1.56 \\
\hline EBITDA (\%) & Derived Parameter & $9 \%$ & $-3 \%$ & $22 \%$ \\
\hline Net Earnings per Piece Sold (INR) & Derived Parameter & 67 & -20 & 178 \\
\hline
\end{tabular}


Table 3: Store level unit economics of online stores for lifestyle brands in India.

\begin{tabular}{|c|c|c|c|}
\hline $\begin{array}{l}\text { Particulars } \\
\text { (An example of Men's Apparel Category) }\end{array}$ & Nature of the Particulars & Online EBO & $\begin{array}{r}\text { Online } \\
\text { Marketplace }\end{array}$ \\
\hline Sizes & Decided by the Lifestyle Brand & S:M:L:XL & S:M:L:XL \\
\hline Size Ratio & Decided by the Lifestyle Brand & $1: 3: 3: 1$ & $1: 3: 3: 1$ \\
\hline Quantity per Size Set (Pieces) & Derived Parameter & 9 & 9 \\
\hline Minimum Size Sets per Store & Decided by the Channel Partner & 1 & 3 \\
\hline Display Options & Decided by the Lifestyle Brand & 556 & 278 \\
\hline Minimum Quantity to be Blocked & Decided by the Lifestyle Brand & 5000 & 7500 \\
\hline Average MRP (INR) & Decided by the Lifestyle Brand & 1446 & 1446 \\
\hline Average Product Base Cost (INR) & Decided by the Lifestyle Brand & 275 & 275 \\
\hline Minimum Blocked Inventory Value at MRP (INR Lacs) & Derived Parameter & 72.30 & 108.45 \\
\hline Minimum Blocked Inventory Value at Cost (INR Lacs) & Derived Parameter & 13.77 & 20.66 \\
\hline Annual Inventory Turns & Decided by the Consumers & 3.42 & 2.85 \\
\hline Sales Quantity (Pieces per Month) & Derived Parameter & 1425 & 1781 \\
\hline Sales MRP Value (INR Lacs per Month) & Derived Parameter & 20.61 & 25.76 \\
\hline Annual Discount Provision (\%) & Decided by the Lifestyle Brand & $49 \%$ & $49 \%$ \\
\hline Discount Value (INR Lacs per Month) & Derived Parameter & 10.03 & 12.54 \\
\hline Gross Merchandise Value (INR Lacs per Month) & Derived Parameter & 10.57 & 13.21 \\
\hline Average Selling Price (INR per Piece) & Derived Parameter & 742 & 742 \\
\hline Secondary Tax (\%) & Decided by the Government & $5 \%$ & $5 \%$ \\
\hline Secondary Tax Value (INR Lacs per Month) & Derived Parameter & 0.50 & 0.63 \\
\hline Cost of Goods Sold (INR Lacs per Month) & Derived Parameter & 3.92 & 4.91 \\
\hline Gross Earning Value (INR Lacs per Month) & Derived Parameter & 6.14 & 7.68 \\
\hline Gross Earning $(\%)$ & Derived Parameter & $58 \%$ & $58 \%$ \\
\hline Returns Quantity (Pieces per Month) & Decided by the Consumers & 499 & 445 \\
\hline Reverse Logistics Cost (INR Lacs per Month) & Derived Parameter & 0.92 & 0.53 \\
\hline Digital Platform Fee (\%) & Decided by the Lifestyle Brand & $15 \%$ & $\mathbf{0 \%}$ \\
\hline Digital Platform Value (INR Lacs per Month) & Derived Parameter & 1.59 & $\mathbf{0}$ \\
\hline Selling Fee (\%) & Decided by the Channel Partner & $\mathbf{0 \%}$ & $16 \%$ \\
\hline Selling Fee Value (INR Lacs per Month) & Derived Parameter & $\mathbf{0}$ & 2.11 \\
\hline Delivery Fee (\%) & Decided by the Channel Partner & $25 \%$ & $16 \%$ \\
\hline Delivery Fee Value (INR Lacs per Month) & Derived Parameter & 2.64 & 2.11 \\
\hline Transaction Fee (\%) & Decided by the Channel Partner & $2 \%$ & $3 \%$ \\
\hline Transaction Fee Value (INR Lacs per Month) & Derived Parameter & 0.21 & 0.40 \\
\hline Digital Promotions Cost (INR Lacs per Month) & Decided by the Lifestyle Brand & 5.50 & 4.10 \\
\hline Warehousing Expenses (INR Lacs per Month) & Decided by the Lifestyle Brand & 0.42 & 0.53 \\
\hline Logistics Expenses (INR Lacs per Month) & Decided by the Lifestyle Brand & 0.21 & 0.26 \\
\hline Shrinkage Provision (INR Lacs per Month) & Decided by the Lifestyle Brand & 0.026 & 0.033 \\
\hline Total Retailing Cost (INR Lacs per Month) & Derived Parameter & 11.52 & 10.08 \\
\hline Net Earning Value (INR Lacs per Month) & Derived Parameter & -5.38 & -2.40 \\
\hline Net Earning (\%) & Derived Parameter & $-51 \%$ & $-18 \%$ \\
\hline Net Earnings per Piece Sold (INR) & Derived Parameter & -378 & -135 \\
\hline
\end{tabular}


Table 4 : Comparative table across various distribution channels and key factors of a lifestyle brand in India.

\begin{tabular}{|c|c|c|c|c|c|c|c|c|}
\hline \multirow[b]{2}{*}{$\begin{array}{l}\text { Factors } \\
\text { (per store per month) }\end{array}$} & \multicolumn{6}{|c|}{ B rick-and-Mortar Stores } & \multicolumn{2}{|c|}{ Online Stores } \\
\hline & $\begin{array}{c}\text { SIS at } \\
\text { National } \\
\text { Retailer } \\
\text { Stores }\end{array}$ & \begin{tabular}{|c|} 
SIS at \\
Regional \\
Retailer \\
Stores
\end{tabular} & $\begin{array}{c}\text { SIS at } \\
\text { Dis tributor } \\
\text { Stores }\end{array}$ & $\begin{array}{c}\text { EBO } \\
\text { High Street } \\
\text { Stores }\end{array}$ & $\begin{array}{c}\text { EBO } \\
\text { Mall } \\
\text { Stores }\end{array}$ & $\begin{array}{c}\text { EBO } \\
\text { Ins titutional } \\
\text { Stores }\end{array}$ & $\begin{array}{c}\text { EBO } \\
\text { Online } \\
\text { Store }\end{array}$ & $\begin{array}{c}\text { Online } \\
\text { Marketplace } \\
\text { Store }\end{array}$ \\
\hline Store Count & 150 & 50 & 400 & 8 & 12 & 4 & 1.00 & 5.00 \\
\hline Carpet Area (SFT) & 267 & 200 & 67 & 2672 & 2672 & 1069 & $\mathrm{Na}^{*}$ & $\mathrm{Na}^{*}$ \\
\hline Trading Area (SFT) & 177 & 133 & 44 & 1774 & 1774 & 710 & $\mathrm{Na}^{*}$ & $\mathrm{Na}^{*}$ \\
\hline Annual Inventory Turns & 4.13 & 2.68 & 1.10 & 2.85 & 2.92 & 2.62 & 3.42 & 2.85 \\
\hline Quantity Sale (Pieces) & 344 & 168 & 23 & 2375 & 2433 & 873 & 1425 & 1781 \\
\hline Discount Percentage & $15.00 \%$ & $15.00 \%$ & $5.12 \%$ & $17.65 \%$ & $17.65 \%$ & $14.26 \%$ & $48.70 \%$ & $48.70 \%$ \\
\hline Revenue (INR in Lacs) & 2.61 & 1.29 & 0.20 & 17.78 & 18.21 & 6.81 & 10.57 & 13.21 \\
\hline Gross Earning (INR in Lacs) & 1.82 & 0.90 & 0.15 & 12.19 & 12.49 & 4.76 & 6.14 & 7.68 \\
\hline Gross Earning Percentage & $66.39 \%$ & $66.39 \%$ & $69.89 \%$ & $65.30 \%$ & $65.30 \%$ & $66.68 \%$ & $58.11 \%$ & $58.11 \%$ \\
\hline Average Selling Price (INR) & 757 & 773 & 862 & 748 & 748 & 779 & 742 & 742 \\
\hline Overall Retailing Cost (INR in Lacs) & 2.77 & 0.83 & 0.10 & 10.60 & 12.99 & 3.21 & 11.52 & 10.08 \\
\hline Net Earning (INR in Lacs) & -0.95 & 0.07 & 0.05 & 1.59 & -0.50 & 1.56 & -5.38 & -2.40 \\
\hline Net Earning Percentage & $-36.63 \%$ & $5.51 \%$ & $23.63 \%$ & $8.93 \%$ & $-2.73 \%$ & $22.89 \%$ & $-50.89 \%$ & $-18.14 \%$ \\
\hline Sale Return Percentage & $1.12 \%$ & $0.95 \%$ & $0.95 \%$ & $1.25 \%$ & $1.09 \%$ & $1.36 \%$ & $34.72 \%$ & $25.08 \%$ \\
\hline Net Earning per Piece Sold (INR) & -277.2 & 42.5 & 203.8 & 66.8 & -20.4 & 178.4 & -377.5 & -134.6 \\
\hline
\end{tabular}

*Na: Not Applicable

Table 5 : Percentage deviation from the lifestyle brand's mean in key factors across various distribution channels.

\begin{tabular}{|c|c|c|c|c|c|c|c|c|}
\hline \multirow[b]{2}{*}{$\begin{array}{l}\text { Factors } \\
\text { (per store per month) }\end{array}$} & \multicolumn{6}{|c|}{ B rick-and-Mortar Stores } & \multicolumn{2}{|c|}{ Online Stores } \\
\hline & $\begin{array}{c}\text { SIS at } \\
\text { National } \\
\text { Retailer } \\
\text { Stores }\end{array}$ & $\begin{array}{c}\text { SIS at } \\
\text { Regional } \\
\text { Retailer } \\
\text { Stores }\end{array}$ & $\begin{array}{c}\text { SIS at } \\
\text { Dis tributor } \\
\text { Stores }\end{array}$ & $\begin{array}{c}\text { EBO } \\
\text { High Street } \\
\text { Stores }\end{array}$ & $\begin{array}{c}\text { EBO } \\
\text { Mall } \\
\text { Stores }\end{array}$ & $\begin{array}{c}\text { EBO } \\
\text { Ins titutional } \\
\text { Stores }\end{array}$ & $\begin{array}{c}\text { EBO } \\
\text { Online } \\
\text { Store }\end{array}$ & $\begin{array}{c}\text { Online } \\
\text { Marketplace } \\
\text { Store }\end{array}$ \\
\hline Carpet Area (SFT) & $35.34 \%$ & $13.78 \%$ & $-158.65 \%$ & $93.53 \%$ & $93.53 \%$ & $83.83 \%$ & $\mathrm{Na}^{*}$ & $\mathrm{Na}^{*}$ \\
\hline Trading Area (SFT) & $35.34 \%$ & $13.78 \%$ & $-158.65 \%$ & $93.53 \%$ & $93.53 \%$ & $83.83 \%$ & $\mathrm{Na}^{*}$ & $\mathrm{Na}^{*}$ \\
\hline Annual Inventory Turns & $67.74 \%$ & $50.28 \%$ & $-21.14 \%$ & $53.24 \%$ & $54.37 \%$ & $49.14 \%$ & $61.04 \%$ & $53.24 \%$ \\
\hline Quantity Sale (Pieces) & $43.72 \%$ & $-15.64 \%$ & $-745.19 \%$ & $91.84 \%$ & $92.04 \%$ & $77.82 \%$ & $86.41 \%$ & $89.13 \%$ \\
\hline Discount Percentage & $-27.66 \%$ & $-27.66 \%$ & $-274.01 \%$ & $-8.49 \%$ & $-8.49 \%$ & $-34.29 \%$ & $60.68 \%$ & $60.68 \%$ \\
\hline Revenue (INR in Lacs) & $43.94 \%$ & $-12.86 \%$ & $-639.02 \%$ & $91.78 \%$ & $91.98 \%$ & $78.54 \%$ & $86.18 \%$ & $88.95 \%$ \\
\hline Gross Earning (INR in Lacs) & $45.07 \%$ & $-10.59 \%$ & $-587.88 \%$ & $91.82 \%$ & $92.01 \%$ & $79.06 \%$ & $83.76 \%$ & $87.01 \%$ \\
\hline Gross Earning Percentage & $-2.89 \%$ & $-2.89 \%$ & $2.27 \%$ & $-4.59 \%$ & $-4.59 \%$ & $-2.44 \%$ & $-17.55 \%$ & $-17.55 \%$ \\
\hline Average Selling Price (INR) & $0.39 \%$ & $2.40 \%$ & $12.56 \%$ & $-0.74 \%$ & $-0.74 \%$ & $3.24 \%$ & $-1.65 \%$ & $-1.65 \%$ \\
\hline Overall Retailing Cost (INR in Lacs) & $55.74 \%$ & $-47.58 \%$ & $-1147.10 \%$ & $88.44 \%$ & $90.56 \%$ & $61.77 \%$ & $89.36 \%$ & $87.83 \%$ \\
\hline Net Earning (INR in Lacs) & $-123.95 \%$ & $220.70 \%$ & $389.29 \%$ & $114.40 \%$ & $-145.93 \%$ & $114.67 \%$ & $-104.25 \%$ & $-109.53 \%$ \\
\hline Net Earning Percentage & $-142.72 \%$ & $184.15 \%$ & $-33.79 \%$ & $275.22 \%$ & $-672.73 \%$ & $168.35 \%$ & $-130.75 \%$ & $-186.25 \%$ \\
\hline Sale Return Percentage & $42.72 \%$ & $32.47 \%$ & $32.47 \%$ & $48.68 \%$ & $41.15 \%$ & $52.83 \%$ & $98.15 \%$ & $97.44 \%$ \\
\hline Net Earning per Piece Sold (INR) & $-142.56 \%$ & $177.33 \%$ & $-42.11 \%$ & $276.52 \%$ & $-676.99 \%$ & $166.14 \%$ & $-131.25 \%$ & $-187.67 \%$ \\
\hline
\end{tabular}

Table 6 : Percentage deviation from the lifestyle brand's mean in key factors across brick-and-mortar and online stores.

\begin{tabular}{|l|c|c|}
\hline $\begin{array}{l}\text { Factors } \\
\text { (per store per month) }\end{array}$ & $\begin{array}{c}\text { B rick-and- } \\
\text { Mortar } \\
\text { Stores }\end{array}$ & $\begin{array}{c}\text { Online } \\
\text { Stores }\end{array}$ \\
\hline Annual Inventory Turns & $-1.18 \%$ & $54.75 \%$ \\
\hline Quantity Sale (Pieces) & $-8.21 \%$ & $88.75 \%$ \\
\hline Discount Percentage & $-25.25 \%$ & $60.68 \%$ \\
\hline Revenue (INR in Lacs) & $\mathbf{- 8 . 0 5 \%}$ & $\mathbf{8 8 . 5 7 \%}$ \\
\hline Gross Earning (INR in Lacs) & $-6.60 \%$ & $86.56 \%$ \\
\hline Gross Earning Percentage & $1.34 \%$ & $-17.55 \%$ \\
\hline Average Selling Price (INR) & $0.15 \%$ & $-1.65 \%$ \\
\hline Overall Retailing Cost (INR in Lacs) & $-7.68 \%$ & $88.11 \%$ \\
\hline Net Earning (INR in Lacs) & $-12.63 \%$ & $92.10 \%$ \\
\hline Net Earning Percentage & $-4.24 \%$ & $30.95 \%$ \\
\hline Sale Return Percentage & $-64.04 \%$ & $97.60 \%$ \\
\hline Net Earning per Pie ce Sold (INR) & $\mathbf{4 . 0 9 \%}$ & $\mathbf{- 1 7 0 . 1 9 \%}$ \\
\hline
\end{tabular}




\section{RECOMMENDED DISTRIBUTION CHANNEL MIX :}

It is inevitable that to achieve the true lifestyle brand image, brand organization must attempt to incorporate these recommendations together and across. The recommended distribution channel mix shall not be effective and efficient if the brand organization attempts to change its existing distribution channel mix in phases or in silos. In table 7 we have derived rational store count ratio across various distribution channels available for lifestyle brands in India based on this detailed empirical research and most importantly taking in to account the unit economics of each channel with respect to building true lifestyle brand image among employees, investors, competitors and consumers mind. The standard ratio determines the overall store level profitability of the lifestyle brand in addition to ensuring appropriate brand spread across the country with proper risk mitigation. It is inevitable for any lifestyle brand in India to have presence across all these distribution channels in spite of their existing pros and cons. All the channels though do not yield expected store level brand profit they could possibly play a different role of building the overall image of the lifestyle brand. For instance, though National retailers fail to generate store level profit for the brand they could possibly help brand to get the National brand image among employees, investors, competitors, and consumers mind merely because of this affiliation. To make it simple to understand, we would like to give an example as to how this standard ratio must be used by any lifestyle brands. Let us assume that a lifestyle brand has plans to have presence over 500 stores across India. The ratio table recommends this lifestyle brand to distribute these 500 stores in to i) 50 stores as SIS at National retailer's stores; ii) 125 stores as SIS at Regional retailer's stores; iii) 250 stores through distributors; iv) 50 EBO high street stores; v) 5 EBO mall stores, and vi) $20 \mathrm{EBO}$ institutional stores in addition to $1 \mathrm{EBO}$ online store; 2 generalists online marketplaces and 1 speciality online marketplace.

In addition to applying recommended ratio it is very important for the lifestyle brands to choose each of these available distribution channels based on the roles they expect them to play for the brand and not based on the general perceptions about these channels in the market. Based on this empirical research we have identified and mapped each of these distribution channels against the role they can play on a scale of i) low; ii) moderate, and iii) high as shown in table 8.

Table 7: Recommended store count ratio for lifestyle brands in India.

\begin{tabular}{|l|c|} 
Store Type & $\begin{array}{c}\text { Recommended } \\
\text { Store Count } \\
\text { Ratio }\end{array}$ \\
\hline SIS at National Retailer Stores & 0.10 \\
\hline SIS at Regional Retailer Stores & 0.25 \\
\hline SIS at Distributor Stores & 0.50 \\
\hline EBO High Street Stores & 0.10 \\
\hline EBO Mall Stores & 0.01 \\
\hline EBO Institutional Stores & 0.04 \\
\hline Total & $\mathbf{1 . 0 0}$ \\
\hline
\end{tabular}

Table 8 : Distribution channel wise expected role matrix for lifestyle brands in India.

\begin{tabular}{|c|c|c|c|c|c|c|c|c|}
\hline Role of Distribution Channel & $\begin{array}{c}\text { SIS at } \\
\text { National } \\
\text { Retailer } \\
\text { Stores }\end{array}$ & $\begin{array}{c}\text { SIS at } \\
\text { Regional } \\
\text { Retailer } \\
\text { Stores }\end{array}$ & $\begin{array}{c}\text { SIS at } \\
\text { Dis tributor } \\
\text { Stores }\end{array}$ & $\begin{array}{l}\text { EBO } \\
\text { High } \\
\text { Street } \\
\text { Stores }\end{array}$ & $\begin{array}{c}\text { EBO } \\
\text { Mall } \\
\text { Stores }\end{array}$ & $\begin{array}{c}\text { EBO } \\
\text { Ins titutional } \\
\text { Stores }\end{array}$ & $\begin{array}{c}\text { EBO } \\
\text { Online } \\
\text { Store }\end{array}$ & $\begin{array}{c}\text { Online } \\
\text { Marketplaces }\end{array}$ \\
\hline Helps in Building Brand Awareness & High & Moderate & Low & High & High & High & Moderate & Low \\
\hline Helps in Building Brand Familiarity & High & High & Moderate & High & High & High & Moderate & Low \\
\hline Store Count Scalability & Moderate & High & High & Low & Low & Low & Low & Low \\
\hline Expected Consumer Loyalty & Low & Moderate & Moderate & High & Moderate & High & Moderate & Low \\
\hline Helps in Testing New Design / Product & Low & Low & Low & Low & Low & Low & High & High \\
\hline Old Stock Liquidation & Low & Low & Low & Moderate & Moderate & Low & High & High \\
\hline True Lifestyle Brand Image Building Capability & High & High & Moderate & High & High & High & High & High \\
\hline Capital Investment Requirment & Low & Low & Low & High & High & Moderate & Low & Low \\
\hline Expected Revenue & Moderate & Moderate & Low & High & High & Low & Low & High \\
\hline Expected Profitability & Low & Moderate & High & Moderate & Low & High & Low & Low \\
\hline Capability of Understanding Consumer & Low & Low & Low & High & High & High & High & Low \\
\hline
\end{tabular}




\section{CONCLUSION :}

If a lifestyle brand considers store's absolute revenue as the key indicator of judging best location for a store, brick-and-mortar EBO stores are best suitable; if the brand considers absolute store level profitability as key indicator for choosing best location for a store, distributor stores are most suitable; if brand considers building a premium brand image in employees, consumers, competitors, and investors mind as the key indicator of judging best location for a store, having a SIS in a National retailers $\mathrm{MBO}$ store is appropriate; if a brand considers quick market penetration then online marketplaces is the best suitable distribution channel, and if the lifestyle brand is interested in overall brand performance with consistent growth and sustainable profits then a rational mix of each of these locations is the ideal solution. Every distribution channel for retailing in India have their own pros and cons, none of them have attained ideal retailing solution, yet all of them are continuously evolving by taking learnings from various retailing formats in the developed countries. In this context, we strongly believe that significant importance must be given to the component 'rational' while determining the ideal distribution channel mix for any lifestyle brand in India. Amongst all the distribution channels available in India EBO is the only channel which enables lifestyle brands to understand, interact and maintain long-term relationship with their consumers better than any other channel. EBO also help lifestyle brands to communicate real-time offerings of the brand across products and promotions in addition to having higher possibilities of showing the real brand experience to consumers. Notwithstanding huge capital investment and commitment for the lifestyle brand, EBO stores probably add more value to the brand on overall brand image in employees, investors, competitors and consumers mind as majority of the variables directly impact overall brand profitability at store level are controlled by the lifestyle brand itself. The rational distribution channel mix if executed efficiently can also possibly attract many new investors in the form of Franchisees who can help the brand in expanding its presence across the country through EBO stores at very minimal or no capital investment and commitment involved. Online channels owing to not requiring the brand to make / block huge inventory could possibly be used to test market new designs, models, and products to get immediate feedback from consumers directly in addition to mitigating the inventory risks involved in new product developments.

\section{SUGGESTIONS TO LIFESTYLE BRANDS IN INDIA :}

Based on this research outcome, we would like to determinedly suggest lifestyle brands in India that, they need to clearly understand the role of every distribution channel in relation to their existing / potential consumers, catchment, and merchandise assortment they offer. Lifestyle brands in India also need to clearly understand every other lifestyle brand's key business objective behind having stores in various distribution channels which are more expensive to operate compared to other channels. few brands may be trying to show exponential growth in their revenue to attract more investors; few brands may be assuming that consumers acquired based on discounts and advertising tactics as their key components of selling proposition are going to be loyal to their brand forever; few brands may be trying to create different perceptions in consumers mind over their brand image, few brands may be opening many EBO stores in premium locations with larger size to tag them as experiential, anchor or destination stores assuming that this effort would lead them to create a premium brand image in consumers, competitors and investors mind; few brands may be expanding their presence in catchment areas irrespective of their target consumer groups to promote their brand to attract new investors, franchisees and licensees; few conglomerates may be trying to show their presence in the lifestyle brand segment to strengthen their group portfolio; few may be selling premium priced products or categories to position themselves as premium lifestyle brands; few may be using online marketplaces to show quick consumer acceptance levels and so on. What is very important is the key business goal of your brand, your target consumer group, target consumer group's attitude towards the distribution channels you are affiliated with and most importantly your aim to establish a true lifestyle brand image in employees, investors, competitors, and consumers mind. Lifestyle brand organizations must be aware that the perspective towards a particular distribution channel might not be same among your employees, investors, competitors and consumers, and one achieves a true lifestyle brand image only when majority of internal and external stakeholder's perspectives / perceptions are same and positive 
towards the brand image. Finally, we would suggest lifestyle brands in India to consider part of a few costly distribution channel expenses to be considered as brand promotional costs.

\section{LIMITATIONS OF RESEARCH :}

The main limitation of this research work is the coverage of various stakeholders viz., number of lifestyle brands, product categories, consumer groups, employees, price positioning, distribution channel partners, and types of distribution channels in deriving the recommended rational distribution channel mix. This might limit the generalizability of research findings to other set of lifestyle brands. The second limitation would be the empirical validation is restricted to few Indian lifestyle brands selected for the study and hence the generalizability of the findings and suggestions to other Indian lifestyle brands. The third limitation would be our ability to carry out an experiment, though we were firm in our approach that, the proposed rational mix has to be tested in the field before we recommend, it was not that easy merely because of the vast scope of the experiment. Unlike other experiments wherein the treatment is limited to few concepts, components or variables this experiment in fact required us to cover practically almost all the elements of the lifestyle brand's Marketing Mix which do require longer duration for preparations prior to testing, longer duration prior to the beginning of extracting the results and longer period of time for the experimentation itself to ensure findings and insights are derived holistically. At best we were able to derive recommendations based on our research findings of similar experiments and empirical studies and we shall in some time implement the recommended rational distribution channel mix with a select Indian lifestyle brand and publish the results. However, as the recommended rational distribution channel mix is being derived based on this empirical and previous experimental research findings [27 - 28], it provides significant input regarding the ways in which Indian lifestyle brands could utilise these recommendations to start their journey towards becoming a 'true lifestyle brand' in a sustainably profitable manner.

\section{SCOPE FOR FURTHER RESEARCH :}

We strongly recommended that the recommended rational distribution channel mix is experimented by researchers and the same is finetuned further if required for Indian lifestyle or non-lifestyle brands. Based on the key business objectives and their target consumer group, Indian lifestyle brands can implement the recommended rational distribution mix on a pilot basis and finetune the same based on real-time findings which can then be implemented on a permanent basis.

\section{REFERENCES :}

[1] Schmitt, B (2012). The consumer psychology of brands. Journal of Consumer Psychology, 22(1), 7-17. DOI: 10.1016/j.jcps.2011.09.005.

[2] http://www.technopak.com/Files/fashion-retail-scenario-in-india.pdf. Retrieved in June 2020.

[3] http://statisticstimes.com/demographics/population-of-india.php. Retrieved in June 2020.

[4] https://www.mckinsey.com/industries/retail/our-insights/the-state-of-fashion-2019-a-year-ofawakening. Retrieved on $05^{\text {th }}$ June 2020.

[5] https://www.amazon.in/b/?ie=UTF8\&node=6648217031\&ref_=topnav_storetab top_ap_mega. Retrieved in June 2020.

[6] Ganesha, H. R., Aithal, P. S. (2020). Establishing True Lifestyle Brand in India: An Integrated Marketing Mix Framework. International Journal of Management, Technology, and Social Sciences (IJMTS), 5(1), 261-284.

[7] Lindquist, J.D (1974), Meaning of Image: A Survey of Empirical and Hypothetical Evidence, Journal of Retailing, 50(4), 29-38.

[8] Hirschman, E. C, Greenberg, B \& Robertson, D (1978), The intermarket reliability of retail image research: an empirical examination, Journal of Retailing, 54(1), 3-12.

[9] Ghosh, A (1994), Retail Management. Forth Worth, TX: The Dryden Press. 
[10] Omar, O (1999), Retail Marketing. London: Pitman Publishing House.

[11] Mazursky, D. and Jacoby, J. (1986). Exploring the development of store images. Journal of Retailing, 62(2), 145-165.

[12]Lassk, F. G (2000). Investigating Aspects of Customer Satisfaction at the c-store: The c-store Product Mix and Image, Journal of Professional Services Marketing, 21(2), 15-26.

[13] Osman, M.Z. (1993). A Conceptual Model of Retail Image Influences on Loyalty Patronage Behaviour, International Review of Retail Distribution and Consumer Research, 2, 138-48.

[14] Newman, A.J \& Cullen, P (2002). Retailing; Environment and Operations. London: Thomson Learning.

[15] Newman, A.J (2003). Some Manipulable Elements of the Service Setting and Their Impact on Company Image and Reputation, International Journal of New Product Development and Innovation Management, 4(3), 287-304.

[16]Lilien, G. L., Kotler, P., \& Moorthy, K. S. (1995). Marketing Models. Prentice Hall.

[17] Sinha, P.K \& Banerjee, A. (2004). Store Choice behaviour in an evolving market, International Journal of Retail \& Distribution Management,32(10), 482-94.

[18] Rosenbloom, B (1983). Store image development and the question of congruency. Darden, W.R., Lusch, R.F. (Eds), Patronage Behaviour and Retail Management, Elsevier Science Publishing Co., Dordrecht, 141-149.

[19] Amirani, S \& Gates, R (1993). An attribute-anchored conjoint approach to measuring store image, International Journal of Retail and Distribution Management,21(5), 30-39.

[20]Backer, J., Levy, M. \& Grewal, D. (1992). An Experimental Approach to Making Retail Store Environmental Decisions, Journal of Retailing, 68(2),445-60.

[21]Day, G. S. and Wensley, R. (1988). Assessing Advantage: A Framework for Diagnosing Competitive Superiority, Journal of Marketing, 52(2), 1-20.

[22]Ellis, B \& Kelly, S. W (1992). Competitive Advantage in Retailing. International Review of Retail, Distribution and Consumer Research, 2(4), 381-396.

[23] Mendes, R. and Themindo, C. J. (2004). Retail locations as a competitive strategy. Pearson education, New Delhi.

[24]Reynolds, Jonathan \& Howard, Elizabeth \& Cuthbertson, Christine \& Hristov, Latchezar (2007). Perspectives on retail format innovation: Relating theory and practice. International Journal of Retail \& Distribution Management. 35. 647-660.

[25] Krishen. S. A., Bui. M, Peter. C. P (2010). Retail kiosks: how regret and variety influence consumption. International Journal of Retail \& Distribution Management, 38(3), 173-189.

[26]Levy, M., Weitz, B. A., and Beitelspacher, L.S., (2012). Retailing Management. (8th Edition), McGraw Hill, Irwin.

[27] Ganesha, H. R., Aithal, P. S. \& Kirubadevi, P. (2020). Ideal Store Locations for Indian Retailers - An Empirical Study. International Journal of Management, Technology, and Social Sciences (IJMTS), 5(1), 215-226.

[28] Ganesha, H. R., Aithal, P. S. \& Kirubadevi, P. (2020). Consumer Affordability in Tier-1, Tier-2 and Tier-3 Cities of India - An Empirical Study. International Journal of Applied Engineering and Management Letters (IJAEML), 4(1), 156-171.

[29] Biel, A. (1993). Converting image into equity. In 'Brand Equity and Advertising', Aaker, D. and Biel, A. (eds), Lawrence Erlbaum Associates, Hillsdale, NJ, pp.67-82. 
[30] Michel Laroche and Robert Sadokierski (1994). Role of confidence in a multi-brand model of intentions for a high-involvement service. Journal of Business Research,29(1), 1-12.

[31] Keller, K. L. (1993). Conceptualizing, measuring, and managing customer-based brand equity. Journal of Marketing, 57, 1-22.

[32] Badenhausen, K. (1996). Blind faith. Financial World, pp. 50-55.

[33] Aaker, D. A. (1991). Managing brand equity. New York: Free Press.

[34] Starčević, S. (2013). Istraživanjekonceptaličnostibrenda u marketingu. Marketing, 44(2), 149-172.

[35] Fournier, S. (1998). Consumers and their brands: Developing relationship theory in consumer research. Journal of Consumer Research, 24(4), 343-373.

[36] Pestana, E. (2014). Osdesafios de logísticanamulticanalidade de serviços. Revista da ESPM, São Paulo, 20(92- 2), 132-135.

[37] Kotler, P., \& Keller, K. (2012). Administração de Marketing. São Paulo : Pearson.

[38] Alvarez, F. J. S. M. (2012). Trade Marketing: a competição no ponto de venda. In: Angelo, C. F., Nielsen, F. A. G., \&Fouto, N. M. M. D. (Coords.), Manual de Varejo no Brasil (pp.146-168). São Paulo : Saint Paul.

[39] D'Andrea, R. (2012). Entropiaem trade marketing. In: Amui, A. M. (Coord.), Trade Marketing: pontos de vista expandidos (pp.116-118). São Paulo : LCTE.

[40] Manduca, C. (2012). Uma visãosobre trade marketing. In: Amui, A. M. (Coord.), Trade Marketing: pontos de vista expandidos (pp.134-136). São Paulo : LCTE.

[41] Rangaswamy, A., \& Van Bruggen, G. H. (2005). Opportunities and Challenges in Multichannel Marketing: an introduction to the special issue. Journal of Interactive Marketing, Spring, 19(2), 5-11.

[42] Noble, S., Shenkan, A. G., \& Shi, C. (2009). The Promise of Multichannel Retailing. McKinsey Quarterly, 4, 1-4. 